Article

\title{
Energy Efficiency for Airtightness and Exterior Wall Insulation of Passive Houses in Hot Summer and Cold Winter Zone of China
}

\author{
Xin Fu, Xiaoqian Qian * and Lina Wang \\ College of Civil Engineering and Architecture, Zhejiang University, 866 Yuhangtang Road, Hangzhou 310058, \\ China; fuxin17@zju.edu.cn (X.F.); mrlinchild@126.com (L.W.) \\ * Correspondence: qianxq1@zju.edu.cn; Tel.: +86-0571-8820-8483
}

Received: 26 May 2017; Accepted: 19 June 2017; Published: 23 June 2017

\begin{abstract}
There exists huge differences in climatic conditions and occupant energy-consuming behavior between Berlin and the "hot summer and cold winter zone of China" (HSCW), which implies that the building energy consumption compositions of two regions are completely different. In this paper, dynamic energy consumption simulation for passive houses with Design Builder software was performed. The results indicated that the improvement of building airtightness and exterior wall insulation can reduce annual heating and cooling load effectively, and more importantly the effect is much stronger on heating load than cooling load. Because of this, the paper proposed that the ratio of heating and cooling electricity consumption $(r)$ should be adopted as an important index in energy efficiency evaluation of passive houses. It would contribute to the reasonable selection of ventilation modes and the exterior wall heat transfer coefficient, and benefit the healthy development of passive houses in HSCW.
\end{abstract}

Keywords: hot summer and cold winter zone; passive house; energy simulation; airtightness; exterior wall insulation; the ratio of heating and cooling electricity consumption

\section{Introduction}

The hot summer and cold winter zone of China (HSCW) refers to the middle and lower reaches of the Yangtze River and surrounding area. The climate here is severe: the mean temperature of the hottest month is between $25^{\circ} \mathrm{C}$ and $30^{\circ} \mathrm{C}$, about $2{ }^{\circ} \mathrm{C}$ higher than other places of the same latitude in the world, while the mean temperature of the coldest month is between $2{ }^{\circ} \mathrm{C}$ and $7{ }^{\circ} \mathrm{C}$, about $8-10{ }^{\circ} \mathrm{C}$ lower than other places of the same latitude in the world [1], and the length of summer and winter is significantly longer than that of transient seasons [2]. Because of these, great demands for cooling in summer and heating in winter exist simultaneously for buildings in HSCW, which brings a certain difficulty to constructing energy efficient buildings in this region. The operation of air condition systems accounts for 50 60\% of residential annual energy consumption and the ownership of air conditioners is still rising rapidly [3]. It has long been discussed, how to reduce building energy consumption in HSCW effectively using different technologies. Many researchers have offered their opinions on optimum insulation thickness of exterior walls, window-wall ratio, external shading, heating and cooling system, etc. [3-6].

The "passive house" is a kind of technical architecture which could achieve nearly zero heating and cooling energy consumption, as well as high levels of indoor environmental comfort. It has very strict requirements on insulation, airtightness, high-quality windows, ventilation systems (heat recovery equipment), and the avoidance of thermal bridges, in order to limit the annual per unit area heating (cooling) demand to less than $15 \mathrm{~kW} \cdot \mathrm{h} /\left(\mathrm{m}^{2} \cdot \mathrm{a}\right)$ and a total primary energy (natural energy that has not been subjected to any conversion or transformation process) demand to less than 
$120 \mathrm{~kW} \cdot \mathrm{h} /\left(\mathrm{m}^{2} \cdot \mathrm{a}\right)$ [7]. In contrast to the earlier low-energy buildings, passive houses place much emphasis on building airtightness after noticing that the heat loss by air infiltration accounts for 25 to $50 \%$ of the total heating load [8]. The concept of passive houses was practiced for the first time in Darmstadt, Germany, and since then it has become more and more popular. By the end of 2014, more than 1 million square meters of useful floor area had undergone the certification scheme set by the Passive House Institute (PHI) [9]. So far, studies on passive houses are mainly distributed in Germany, Switzerland, Austria and Central Europe, etc. [10]. Mihai et al. [10] analyzed the energy performance of a passive house located in Bucharest, Romania, which had building system that had the earth-air heat exchange technology combined with photovoltaic panels. Both the Energy Plus simulation and actual measurement were used in this work. Persson et al. [11] studied a case of a passive house in Sweden using the DEROBLTH software to evaluate the feasibility of new technologies, such as windows. The results showed that the solar heat gain through windows can contribute well to the heating of space in passive houses. Audenaert et al. [12] and Dan et al. [13] both analyzed the economic aspect of passive houses and calculated the period of recovery of investment. Georges et al. [14] studied the application of wooden stoves in passive houses under cold climates, using dynamic simulation (TRNSYS) on a typical Norwegian house. Projects in Germany and similar climates demonstrated that passive houses generally make 80 to $90 \%$ less heating energy than conventional new buildings, at additional building costs of 5 to $20 \%$ [9].

In 2007 passive houses were formally introduced to China. Since then several trial projects have been completed or under construction, as shown in Figure 1 [15]. It confirms that China is capable of building passive houses. However, it can be seen that most practices are located in severe cold or cold zones in China. The passive house concept is based on reducing heating losses [16], not in accordance with the fact that in HSCW, cooling load accounts for a considerable proportion of building consumption. It is still worth deep discussion on whether passive houses can be a feasible solution to building energy efficiency problems in HSCW, and what adjustments should be made to the passive house standards, on account of the special climatic conditions in HSCW. This paper presents the dynamic energy consumption simulation results for passives houses, analyzes the effect of building airtightness and insulation on energy consumption, and aims to evaluate the adaptability of passive houses in HSCW from an energy consumption point of view.

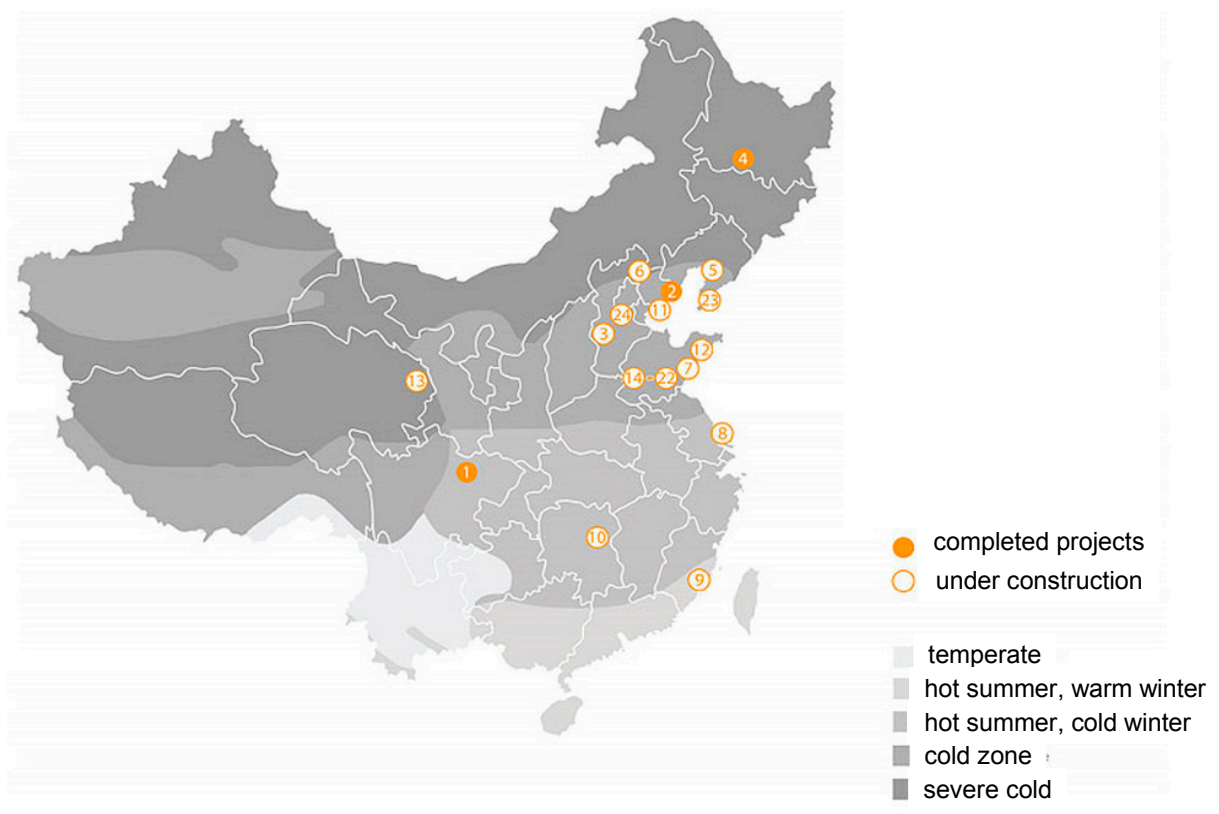

Figure 1. Passive house projects in China. 


\section{Program and Experimental Verification}

Energy-Plus is a building energy simulation program that builds on the strengths of BLAST and DOE-2. It is based on the Transfer Function Method (TFM) [17]. Design Builder is the first graphic user interface software developed specifically for Energy-Plus in order to resolve the inefficiency of an unfriendly interface [18].

In order to test the accuracy of Design Builder results, a full scale experimental building in Hangzhou was examined under real-time temperature monitoring and the results are used for comparison with the simulation on the corresponding model. Figure 2 shows the experimental building. The configuration of the exterior wall is $240 \mathrm{~mm}$ ceramsite aerated concrete block $+15 \mathrm{~mm}$ thermal mortar + ceramic tiles. The surface temperature of the envelope was measured by platinum resistance temperature sensor and the step size is $20 \mathrm{~min}$. A meteorological station was erected on the roof to measure ambient temperature, relative humidity, solar radiation, wind speed and direction, etc. The actual measured data was imported into Design Builder for this part of simulation. Figures 3 and 4 show the temperature reading module and station. The internal and external surface temperature ( $\mathrm{T}_{\mathrm{IS}}$ and $\mathrm{T}_{\mathrm{ES}}$ ) on the south exterior wall of a room on the second floor has been chosen for illustration. Figure 5 shows the measured and calculated values on 14-16 January and 6-8 July 2016. It can be seen that there are overall good agreements between simulation and measurement results.

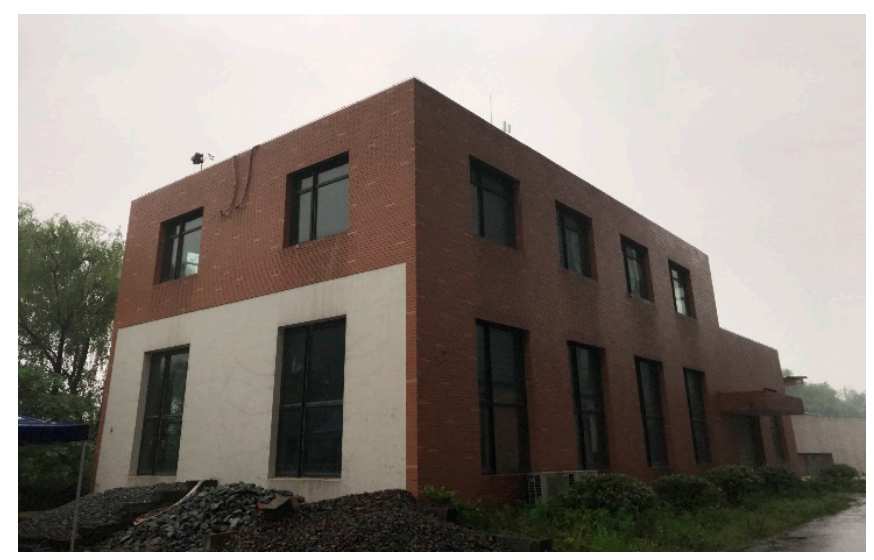

Figure 2. The experimental building.

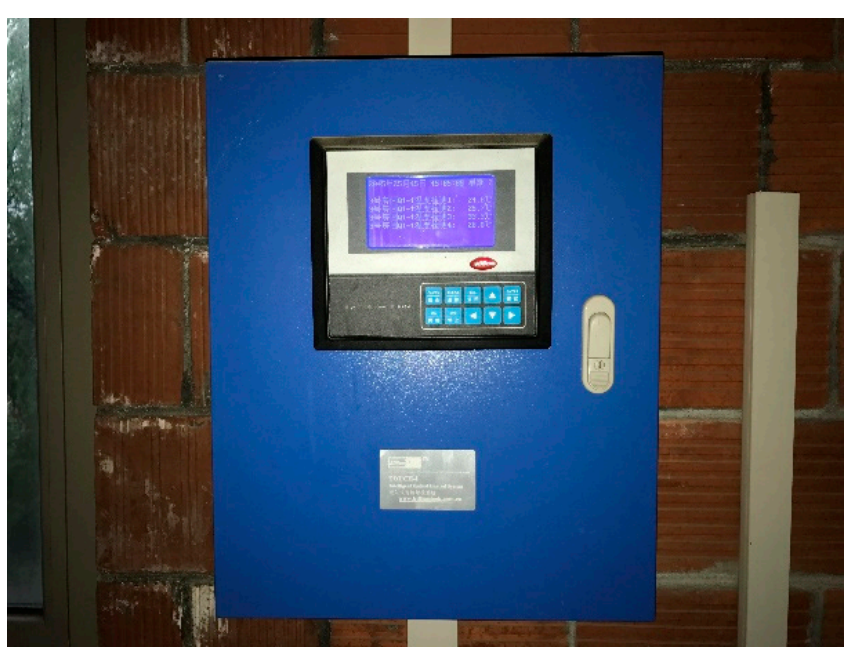

Figure 3. Temperature reading module. 


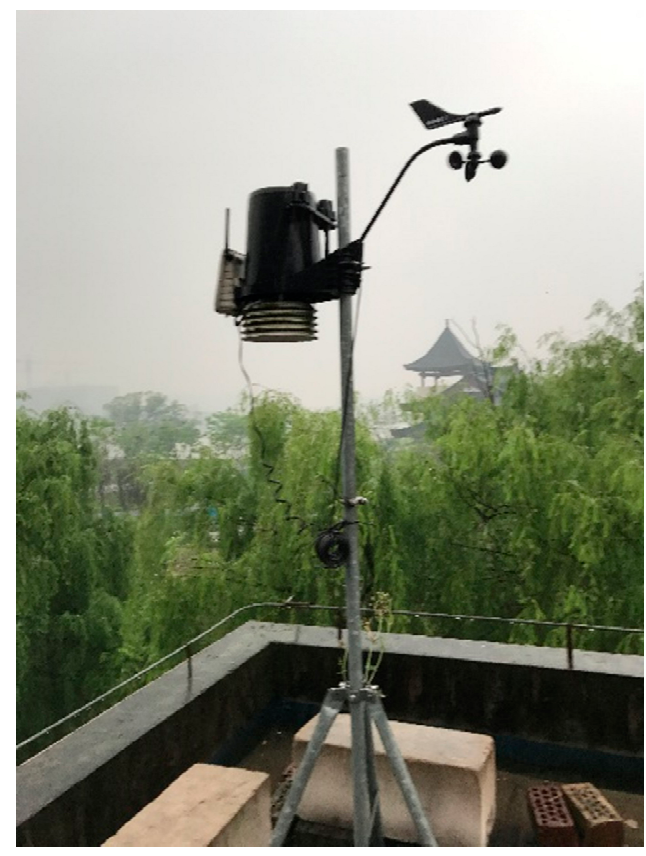

Figure 4. The meteorological station.

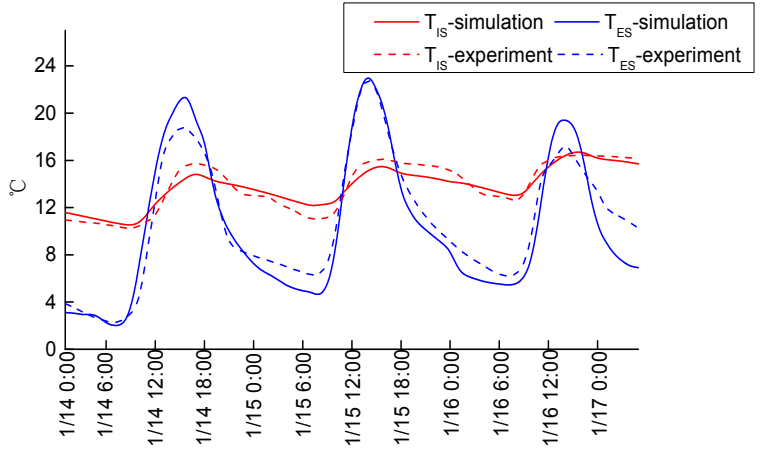

(a)

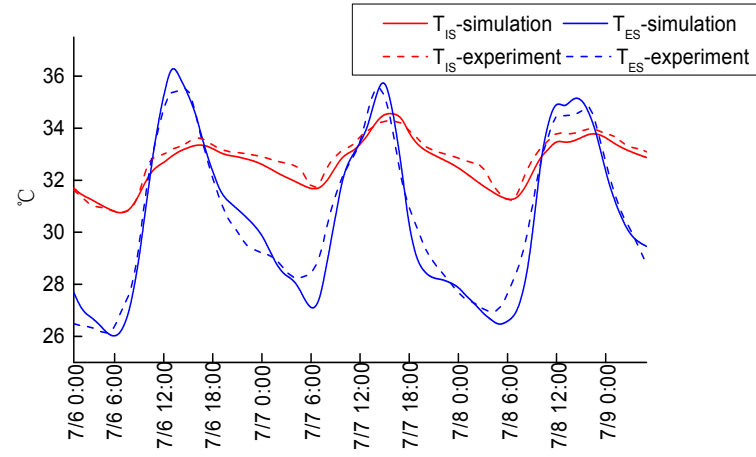

(b)

Figure 5. Internal and external surface temperature of exterior wall in simulation and measurement (a) 14 to 16 January 2016; (b) 6 to 8 July 2016.

\section{Simulation Arrangement}

The simulation model is a three-floor residential building. Only the results of the central floor have been reported. The standard floor area is $260.64 \mathrm{~m}^{2}$ and the floor height is $3 \mathrm{~m}$, as shown in Figure 6 . External insulation is applied to the building envelope. For passive houses the thermal parameters of envelope takes from the passive house standard ("Certification Criteria for Residential Passive House Buildings") [7]. A reference case is set for comparison, whose envelope thermal parameters takes from the industry standard in HSCW ("Design standard for energy efficiency of residential buildings in hot summer and cold winter zone") [19], shown in Table 1. The air conditioning (AC) system operates continuously. The heating setpoint temperature is $18^{\circ} \mathrm{C}$ and the coefficient of performance (COP) is 1.9. The cooling setpoint temperature is $26^{\circ} \mathrm{C}$ and the COP is 2.3. Average internal heat gain intensity is $4.3 \mathrm{~W} / \mathrm{m}^{2}$ [19]. Five typical cities in $\mathrm{HSCW}$ were selected for simulation and the Chinese Standard Weather Data (CSWD) was used for climate data. In addition, for comparison with the regions where the passive house technology is well established, Berlin was selected as a typical German city. DEU_BERLIN_IWEC was used as the climatic data. 
Table 1. Thermal parameters of envelope.

\begin{tabular}{|c|c|c|c|}
\hline \multirow{2}{*}{ Envelope } & \multirow{2}{*}{ Configuration } & \multicolumn{2}{|c|}{ Heat Transfer Coefficient $\left(\mathrm{W} /\left(\mathrm{m}^{2} \cdot \mathrm{K}\right)\right)$} \\
\hline & & Passive Houses & Reference Case \\
\hline Exterior wall & $\begin{array}{l}10 \mathrm{~mm} \text { cement plaster }+240 \mathrm{~mm} \text { brick }+\mathrm{a} \\
\text { certain thickness of polystyrene board }+10 \mathrm{~mm} \\
\text { cement plaster }\end{array}$ & 0.15 & 1.5 \\
\hline Roof & $\begin{array}{l}10 \mathrm{~mm} \text { cement plaster }+ \text { a certain thickness of } \\
\text { polystyrene board }+100 \mathrm{~mm} \text { reinforced } \\
\text { concrete }+10 \mathrm{~mm} \text { cement plaster }\end{array}$ & 0.15 & 1.0 \\
\hline Exterior windows & double-layer hollow glass & $0.85(\mathrm{SHGC}=0.40)$ & $4.0(\mathrm{SHGC}=0.75)$ \\
\hline
\end{tabular}

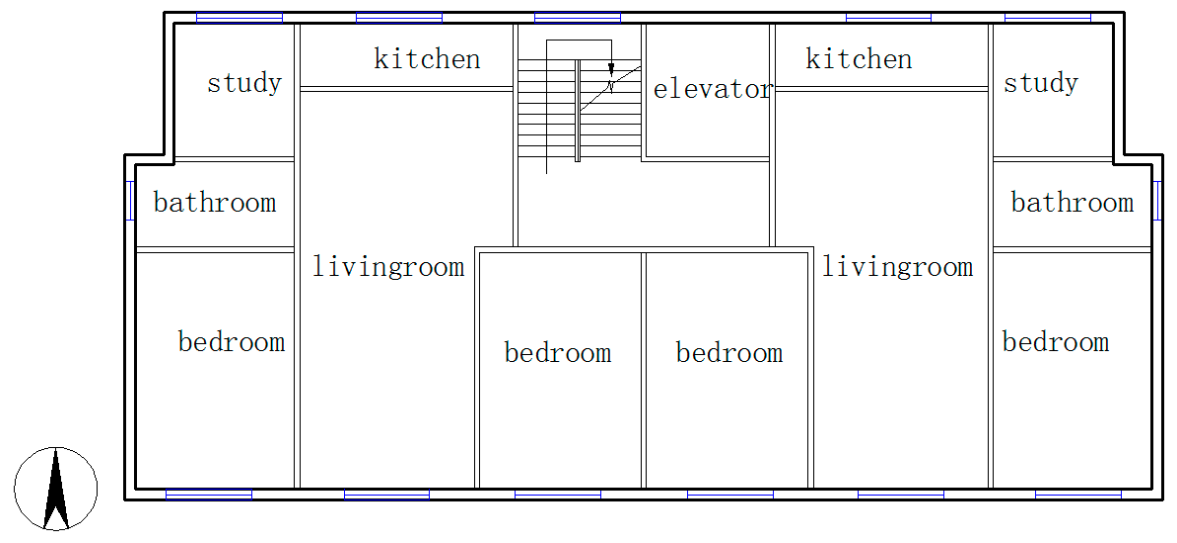

Figure 6. Standard floor plan.

\section{Results and Discussion}

\subsection{Climatic Condition}

Figure 7 shows the daily average temperature in typical meteorological years for six cities. It is obvious that Berlin has lower temperatures all year round than any of the cities in HSCW. To further demonstrate this difference, the average temperature in the coldest and hottest month $\left(\mathrm{T}_{\mathrm{C}}\right.$ and $\left.\mathrm{T}_{\mathrm{H}}\right)$ and the numbers of days in which the daily average temperature is less than or equal to $5{ }^{\circ} \mathrm{C}$ (more than or equal to $\left.25^{\circ} \mathrm{C}\right)\left(\mathrm{X}_{\mathrm{C}}\right.$ and $\left.\mathrm{X}_{\mathrm{H}}\right)$ are compared in Figures 8 and 9 respectively. All of the above four indexes are the basis for climatic division in relevant standards of China [20]. It is found that $\mathrm{T}_{\mathrm{C}}$ of Berlin is 1.9 ${ }^{\circ} \mathrm{C}$, while those of five $\mathrm{HSCW}$ cities range from 2.0 to $7.5^{\circ} \mathrm{C}$. Only in Hanzhong and Nanjing were the values close to Berlin. $\mathrm{T}_{\mathrm{H}}$ of Berlin is merely $19.1^{\circ} \mathrm{C}$, far lower than those of five HSCW cities which range from 25.6 to $27.4{ }^{\circ} \mathrm{C}$. In addition, Berlin's $\mathrm{X}_{\mathrm{C}}$ is $116 \mathrm{~d}$ while $\mathrm{X}_{\mathrm{H}}$ is merely $5 \mathrm{~d}$, the ratio of the two can reach 23.2. But for HSCW cities, the maximum ratio is merely 1.4 for Hanzhong, the minimum is 0.1 for Guilin. Therefore, there exists huge difference of climatic conditions between Berlin and HSCW. Summer and winter are both cooler in Berlin, and in summer it would be more significant.

Climatic conditions have a deep influence on actual occupant heating and cooling behaviors, and furthermore, will affect the building energy consumption composition. So it should be noted that just because passive houses can achieve excellent energy-saving effects, it does not mean that they are applicable in HSCW too. Detailed analysis combined with actual climatic conditions is necessary on the adaptability of passive houses in this region. 


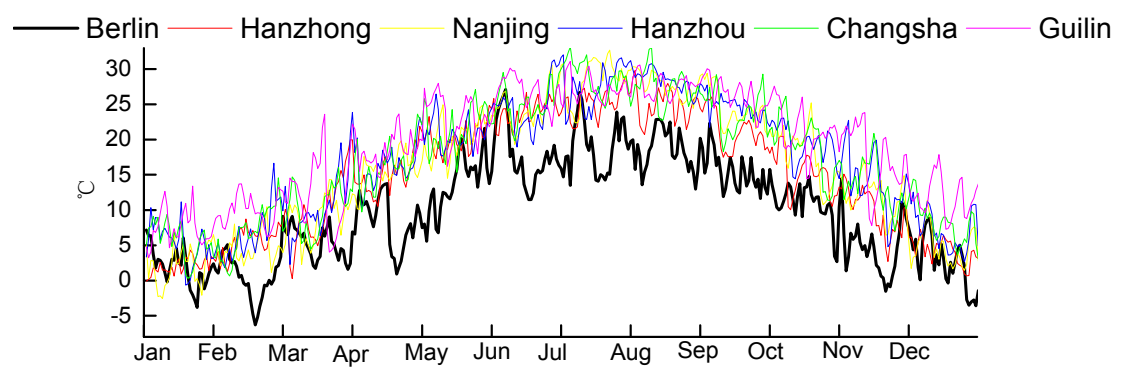

Figure 7. Daily average temperature.

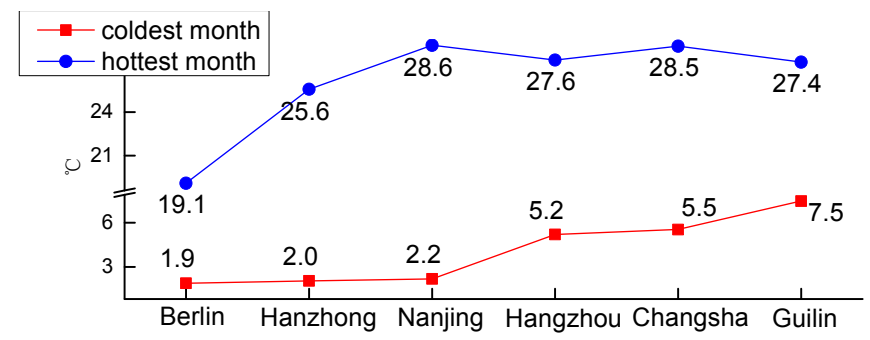

Figure 8. Average temperature in the coldest and hottest month.

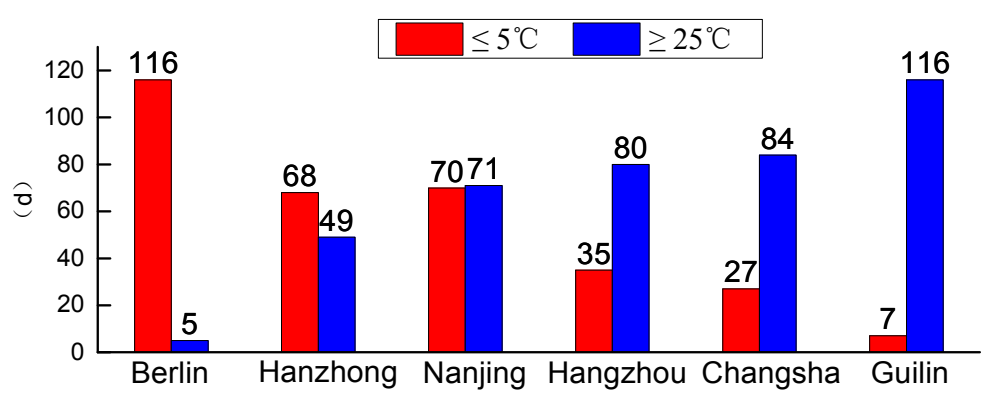

Figure 9. Numbers of days in which daily average temperature is $\leq 5^{\circ} \mathrm{C}$ for winter period and $\geq 25^{\circ} \mathrm{C}$ for summer period.

\subsection{Airtightness}

Passive houses have strict requirements for building airtightness. In order to find the optimal airtightness for passive houses in HSCW, three different ventilation modes are considered here: (1) Mode $1: 1.0 \mathrm{ac} / \mathrm{h}$ for average natural infiltration rate $(\mathrm{ACH})$. This value comes from the industry standard in HSCW, which reflects the current situation that the airtightness of existing buildings is poor due to the late start of building energy-saving in HSCW. For the reference case the ACH is $1.0 \mathrm{ac} / \mathrm{h}$ as well; (2) Mode 2: $0.5 \mathrm{ac} / \mathrm{h}$ for ACH. Previous studies have shown that when indoor air exchange rate is below $0.5 \mathrm{ac} / \mathrm{h}$, many health problems would occur [21]. For this reason many European relevant standards limit the ACH to not lower than $0.5 \mathrm{ac} / \mathrm{h}$ [22]. In severe cold and cold zones of China, the $\mathrm{ACH}$ is $0.5 \mathrm{ac} / \mathrm{h}$ as well [23]. For Mode 1 and 2, since the natural infiltration can satisfy the basic indoor fresh air demand, mechanical ventilation is no longer needed; (3) Mode 3: $0.6 \mathrm{ac} / \mathrm{h}$ for average natural infiltration rate when the building envelope is subjected to a $50 \mathrm{~Pa}$ pressure $\left(\mathrm{ACH}_{50}\right)$. This value comes from the passive house standard, which recognizes that naturally, the pressure subjected to the envelope would not reach $50 \mathrm{~Pa}$, and it can be converted between $\mathrm{ACH}$ and $\mathrm{ACH}_{50}$ with Equation (1):

$$
\mathrm{ACH}_{50}=\mathrm{ACH} / n,
$$


where $n$ is correlation factor related with the climate, stack effect, etc. For Chinese buildings $n=17$ [24]. So $0.6 \mathrm{ac} / \mathrm{h}$ for $\mathrm{ACH}_{50}$ is equal to $0.035 \mathrm{ac} / \mathrm{h}$ for $\mathrm{ACH}$ (close to 0 ). For Mode 3 mechanical ventilation must be employed to satisfy fresh air demand. In the simulation, the strength of mechanical ventilation is set to $0.5 \mathrm{ac} / \mathrm{h}$ and the electrical efficiency is $0.45 \mathrm{Wh} / \mathrm{m}^{3}$ with $75 \%$ heat recover efficiency. It would operates all the day.

The distribution of annual indoor heat gain and loss in different modes is first analyzed, and Hangzhou is used as an example. If natural ventilation is not carried out, it is shown in Figure 10a that in heating period, the ACH decreasing heat loss for natural infiltration ( $\mathrm{Q}_{\mathrm{INF}}$ ) can be reduced significantly. When compared to Mode 2, even the heat loss for mechanical ventilation ( $\left.\mathrm{Q}_{\mathrm{MV}}\right)$ is additional, and in Mode 3, the total heat loss is still less. Considering that the solar heat gain through windows and internal heat gain $\left(\mathrm{Q}_{\mathrm{SO}}\right.$ and $\left.\mathrm{Q}_{\mathrm{I}}\right)$ are identical in three modes, the annual heating load $\left(\mathrm{Q}_{\mathrm{AC}}\right)$ would be reduced. Compared with Mode 1, $\mathrm{Q}_{\mathrm{AC}}$ is reduced by $63.0 \%$ in Mode 2 and $94.4 \%$ in Mode 3. It is very close to 0 in Mode 3, which means in this condition $Q_{S O}$ and $Q_{I}$ can basically satisfy the indoor heating demand. As for cooling period, it can be found in Figure 10b that the effect on QINF of $\mathrm{ACH}$ is much weaker than in heating period. As a result, when compared with Mode $1, \mathrm{Q}_{\mathrm{AC}}$ is reduced by $5.8 \%$ in Mode 2 and $11.3 \%$ in Mode 3, much lower than heating load. In conclusion, annual heating and cooling load are both reduced with decreasing $\mathrm{ACH}$, and the effect on the heating load is more significant.

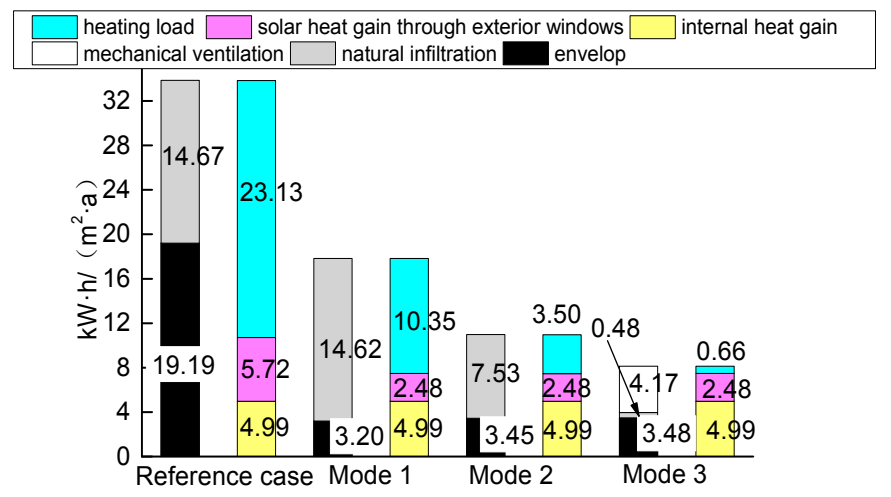

(a)

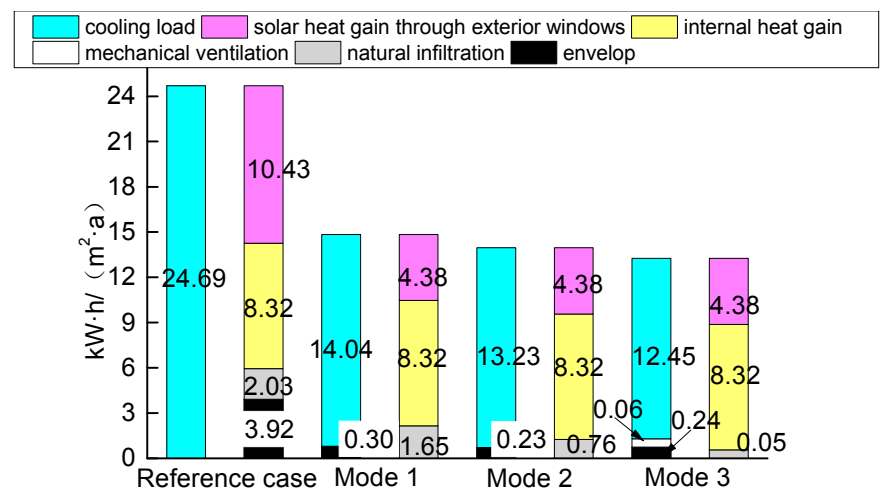

(b)

Figure 10. Distribution of heat gain and loss without natural ventilation in Hangzhou (a) heating period; (b) cooling period (In one case, former column represents heat loss, latter column represents heat gain, the same below).

For buildings in HSCW, during night and early morning in summer, outdoor temperature might drop to lower than indoor temperature. In this period residents can open exterior windows, and take full advantage of natural ventilation to lower the indoor temperature. Adding natural ventilation 
in the Design Builder program, the air exchange rate during natural ventilation is $0-5.0 \mathrm{ac} / \mathrm{h}$ and it operates only when outdoor temperature is lower than indoor temperature in summer. From the comparison of Figures $10 \mathrm{~b}$ and 11, it can be seen that with natural ventilation operating the annual cooling load can be reduced significantly in all cases. The reduction percent is $6.3 \%, 14.0 \%, 20.8 \%$ and $23.7 \%$ for reference case and three modes respectively. The heat dissipation effect by natural ventilation operating in a certain period is much better than that by mechanical ventilation. So natural ventilation has an excellent effect on cooling energy-saving and should be made good use of.

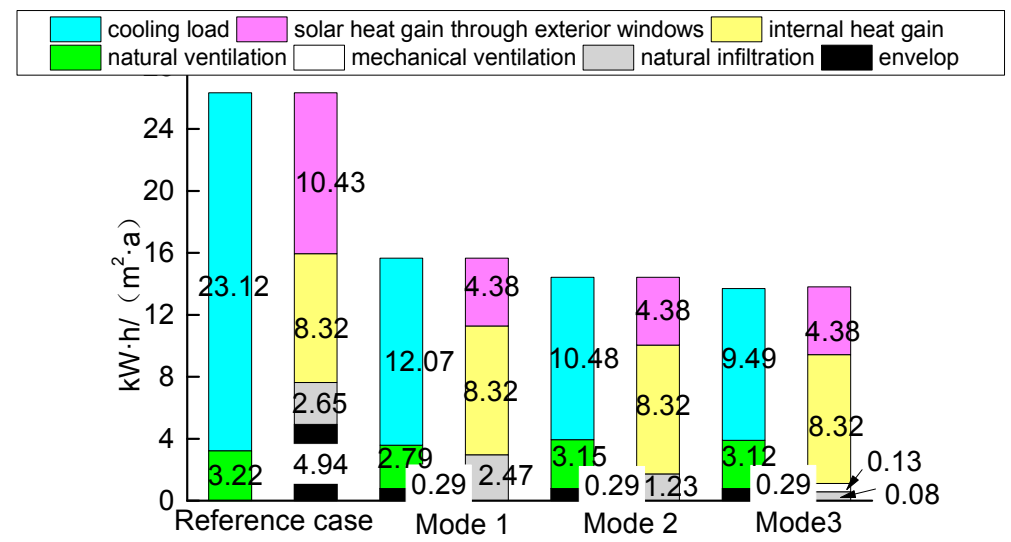

Figure 11. Effect of natural ventilation on cooling load.

Secondly the total annual electricity consumption (only including heating, cooling and mechanical ventilation) in different modes is analyzed. Equation (2) is the transformation formula of heating or cooling load and electricity consumption:

$$
\mathrm{HE} \text { or } \mathrm{CE}=\mathrm{Q}_{\mathrm{AC}} / \mathrm{COP},
$$

where HE is the annual heating electricity consumption and CE is the annual cooling electricity consumption, COP is 1.9 for heating and 2.3 for cooling. As shown in Figure 12, the comparative result of annual total electricity consumption in different modes is: Reference case $>$ Mode $3>$ Mode 1 $>$ Mode 2. Compared with Mode 1 and Mode 2, although there is a certain reduction of annual heating and cooling consumption in Mode 3, this reduction is still not enough to neutralize the accompanying annual mechanical ventilation consumption. As for other cities, shown in Figure 13, the total consumption in Mode 3 is always higher than in Mode 2, except for Berlin. In Berlin, the reduction of annual heating and cooling consumption can reach $6.01 \mathrm{~kW} \cdot \mathrm{h} /\left(\mathrm{m}^{2} \cdot \mathrm{a}\right)$, much higher than five HSCW cities, and this value exceeds mechanical ventilation consumption. So only in Berlin the annual total consumption in Mode 3 is lower than Mode 2. The reason lies in the difference of building energy consumption composition between Berlin and HSCW. Since summer and winter are both cooler in Berlin, annual heating demand is higher and cooling demand is lower. The ratio of heating and cooling electricity consumption $(r)$ is used to characterize this energy consumption composition. The calculation formula is:

$$
r=\mathrm{HE} / \mathrm{CE},
$$

As seen in Figure 14, for Berlin the $r$ value can reach 42.4 and 13.1 in Mode 2 and Mode 3, while for HSCW cities, the average is only 0.7 and 0.1. It has been confirmed that the effect of ACH on heating load is more significant than cooling load, which means in cities with a bigger $r$ value, the improvement of building airtightness can achieve better energy efficiency. However, for HSCW cities the $r$ is generally small, therefore the total electricity consumption in Mode 3 is higher instead due to adding mechanical ventilation electricity consumption. 
In conclusion, although it could not be ignored that mechanical ventilation may generate improvement of indoor air environment, from an energy-saving point of view, Mode 3 is not the most applicable ventilation mode for passive houses in HSCW, which is required by the passive house standard.

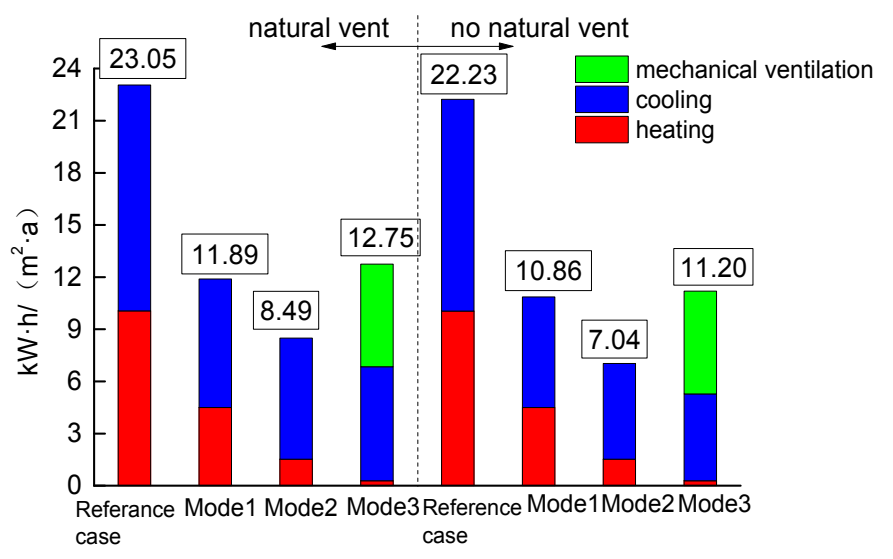

Figure 12. Annual electricity consumption in Hangzhou.

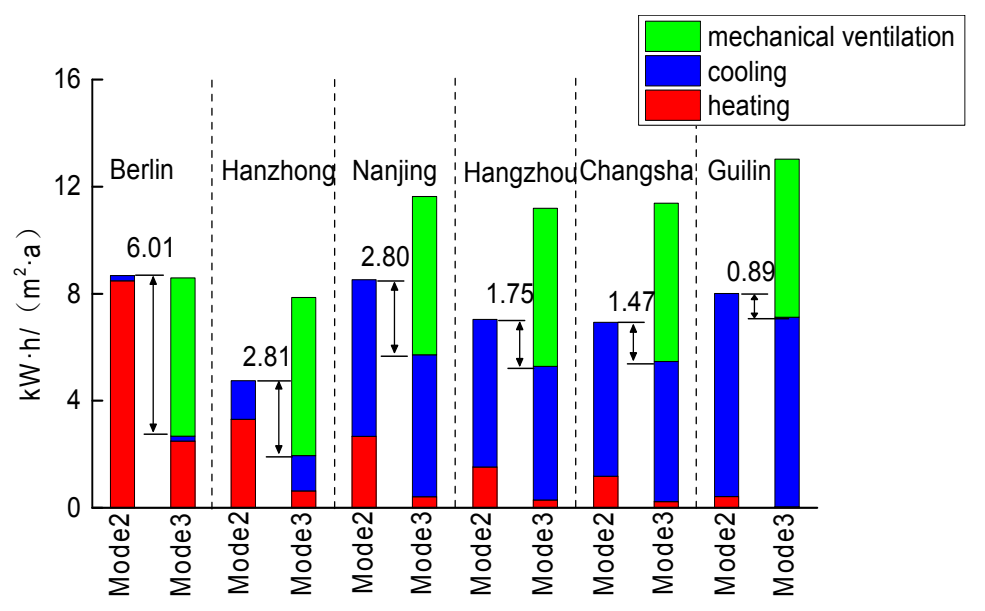

Figure 13. Annual electricity consumption in Mode 2 and Mode 3 in different cities (with natural ventilation).

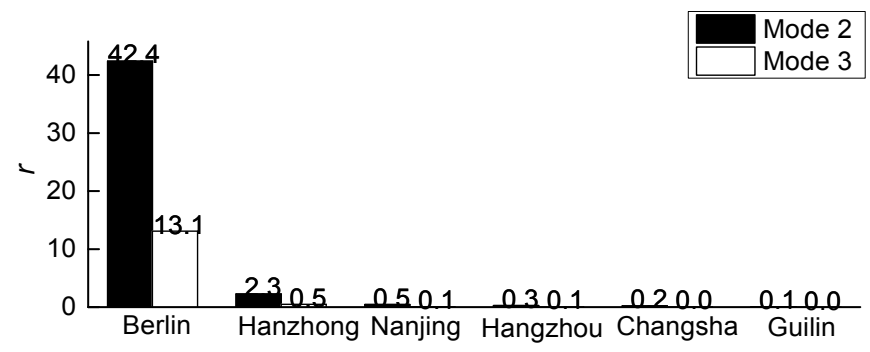

Figure 14. The ratio of heating and cooling electricity consumption.

\subsection{Exterior Wall Insulation}

Besides ventilation, the envelope insulation is another important content in the passive house standard. In this part of simulation, the ventilation mode is set as Mode 2 and Mode 3 respectively, and exterior wall heat transfer coefficient $(\mathrm{U})$ varies from 0.15 to $1.50 \mathrm{~W} /\left(\mathrm{m}^{2} \cdot \mathrm{K}\right)$ by each 0.15 gap. $0.15 \mathrm{~W} /\left(\mathrm{m}^{2} \cdot \mathrm{K}\right)$ is the value in the passive house standard for HSCW. 
Natural indoor temperature $\left(\mathrm{T}_{\mathrm{NA}}\right)$ can reflect the comprehensive regulation of envelope to ambient climatic conditions and occupant behavior without air-conditioning. Hangzhou as an example, as shown in Figure 15, with the $U$ value decreasing, the average $T_{N A}$ in the coldest month rises gradually and in the hottest month it drops. The effect on the former is much more remarkable. When $\mathrm{U}$ is equal to $0.15 \mathrm{~W} /\left(\mathrm{m}^{2} \cdot \mathrm{K}\right)$, compared with the reference case, average $\mathrm{T}_{\mathrm{NA}}$ in the coldest month rises up to $5.7^{\circ} \mathrm{C}$ in Mode 2 and $14.9^{\circ} \mathrm{C}$ in Mode 3, and it rises faster with $\mathrm{U}$ decreasing. In the hottest month the average $\mathrm{T}_{\mathrm{NA}}$ merely drops $0.8^{\circ} \mathrm{C}$. So it can be concluded that the improvement of exterior wall insulation can enhance indoor thermal environment of passive houses in both summer and winter.

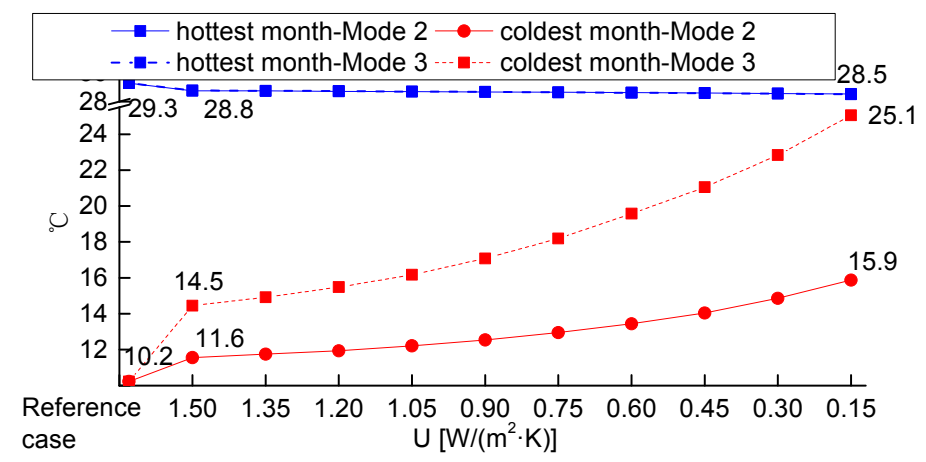

Figure 15. Average natural indoor temperature in the hottest and coldest month.

When air-conditioning operates, Figure 16 shows that the numbers of annual heating and cooling hours decrease simultaneously with the $U$ value decreasing. When $U$ is equal to $0.15 \mathrm{~W} /\left(\mathrm{m}^{2} \cdot \mathrm{K}\right)$, compared with the reference case, the number of annual heating hours decreases by $234 \mathrm{~h}(18.1 \%)$ in Mode 2 and $738 \mathrm{~h}(57.1 \%)$ in Mode 3, and it decreases faster with $\mathrm{U}$ decreasing. The number of annual cooling hours merely decreases by about $3 \%$.

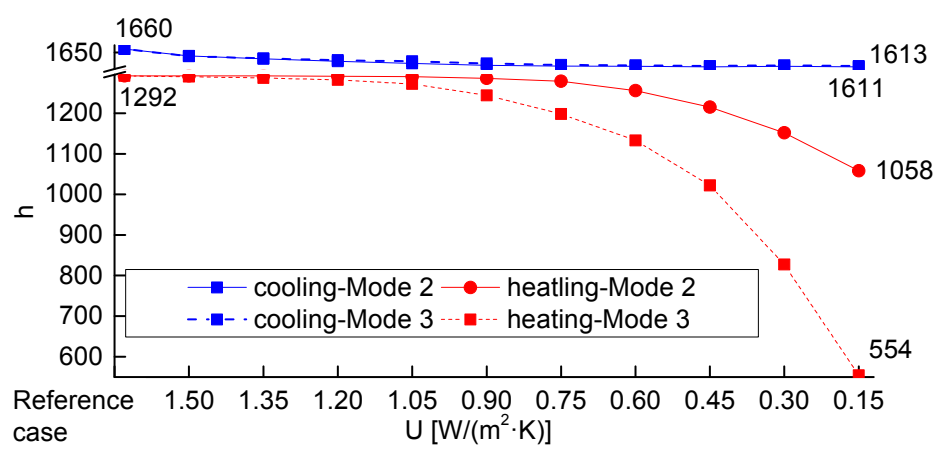

Figure 16. Annual heating and cooling hours.

On the basis that the improvement of exterior wall insulation can enhance indoor thermal environment and reduce annual heating and cooling hours, it generates a certain reduction of annual heating and cooling electricity consumption, as shown in Figure 17. Energy saving rate $(R)$ is used to characterize the energy saving effect. For the reference case the $R$ value is 50\% [10]. It actually means that when compared with traditional buildings without insulation, the annual energy consumption of reference case is $50 \%$ lower. Therefore, $\mathrm{R}$ can be calculated by Equation (4):

$$
\mathrm{R}=\left(\mathrm{AE}_{0} / 50 \%-\mathrm{AE}_{\mathrm{i}}\right) /\left(\mathrm{AE}_{0} / 50 \%\right) \times 100 \%,
$$

where $\mathrm{AE}_{\mathrm{i}}$ is annual total electricity consumption at a certain $U$ value and $\mathrm{AE}_{0}$ is annual total electricity consumption of the reference case. When $\mathrm{U}$ is equal to $0.15 \mathrm{~W} /\left(\mathrm{m}^{2} \cdot \mathrm{K}\right), \mathrm{R}$ can reach $84.2 \%$ in Mode 2 
and $74.8 \%$ in Mode 3. Figure 18 shows the distribution of heat gain and loss in Mode 2 in Hangzhou. In heating period, compared with the case $\mathrm{U}=1.50 \mathrm{~W} /\left(\mathrm{m}^{2} \cdot \mathrm{K}\right), \mathrm{Q}_{\mathrm{E}}$ is $10.69 \mathrm{~kW} \cdot \mathrm{h} /\left(\mathrm{m}^{2} \cdot \mathrm{a}\right)$ lower when $\mathrm{U}$ is equal to $0.15 \mathrm{~W} /\left(\mathrm{m}^{2} \cdot \mathrm{K}\right)$, which results in about a $75 \%$ reduction of annual heating load. In the cooling period, the variation of $\mathrm{Q}_{\mathrm{E}}$ comes to $6.09 \mathrm{~kW} \cdot \mathrm{h} /\left(\mathrm{m}^{2} \cdot \mathrm{a}\right)$, and results in about $35 \%$ reduction of annual cooling load. The effect on heating load is more remarkable.

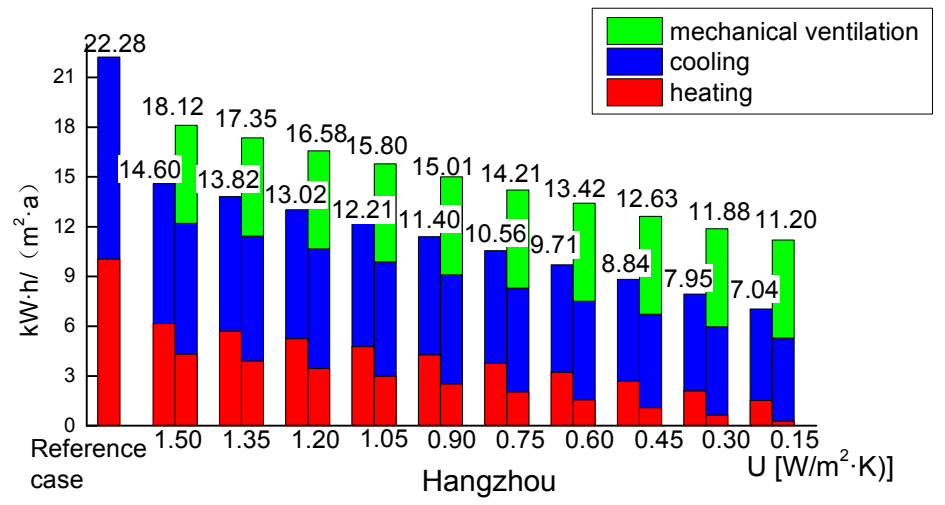

Figure 17. Annual electricity consumption in Hangzhou.

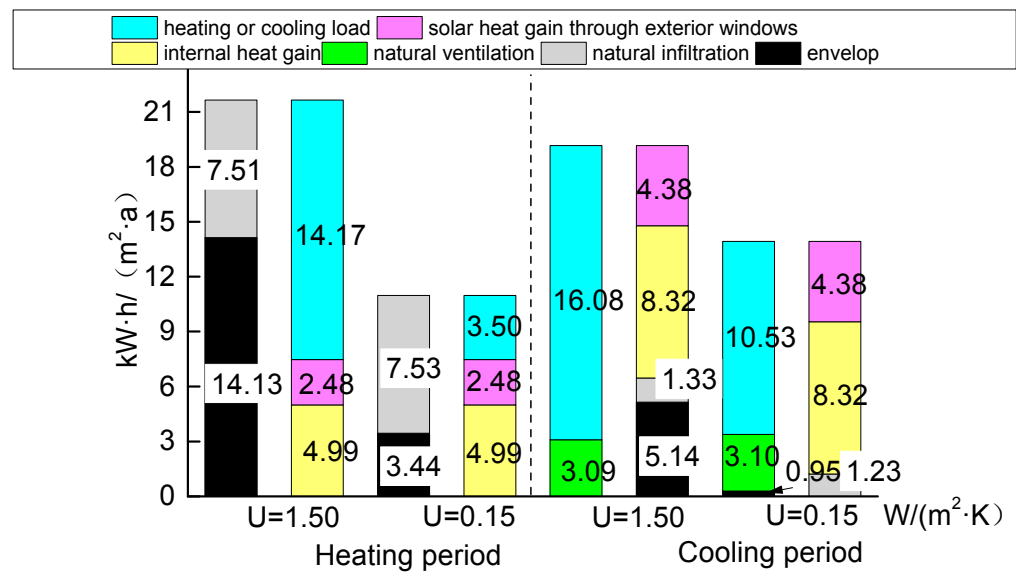

Figure 18. Distribution of heat gain and loss when $U=0.15$ and 1.50 (Mode 2 in Hangzhou).

Therefore, the improvement of exterior wall insulation can generate a significant reduction of annual total energy consumption. Besides, there exists difference among different cities. As shown in Figures 19 and 20, when the ventilation mode and $U$ value is certain, $R$ is always highest in Hanzhong, the coldest city of the five and lowest in Guilin, the hottest city. The relationship of $R$ and $U$ is nearly linear. In the same ventilation mode, the slope of U-R line is biggest for Hanzhong and smallest for Guilin. It means the improvement of exterior wall insulation can achieve better energy-saving effects in colder cities. The reason lies in the different ratio of heating and cooling electricity consumption $(r)$ as well. It has been confirmed that the effect of exterior wall insulation on heating load is more significant than cooling load, in colder cities the $r$ value is smaller, the annual energy-saving effect caused by exterior wall insulation is better consequently. Additionally, the $\mathrm{R}$ value is always bigger in Mode 2 than Mode 3, which again evidences the conclusion of Section 4.2.

From the analysis in Sections 4.2 and 4.3, it can be seen that the ratio of heating and cooling electricity consumption $(r)$ becomes an important index in energy efficiency evaluation of passive houses. Considering that improvement of building airtightness and exterior wall insulation, both have a better energy-saving effect on heating load, it actually implies that passive houses can achieve higher energy efficiency in the region with a bigger $r$ value like Berlin. However, in HSCW the $r$ value is 
generally small, and therefore, the adaptability of the passive house standard should be reevaluated. Climatic conditions would affect actual occupant heating and cooling behaviors, and become a critical factor of $r$. It is beneficial to the healthy development of passive houses in HSCW if taking $r$ into consideration when selecting the most reasonable airtightness level and insulation construction.

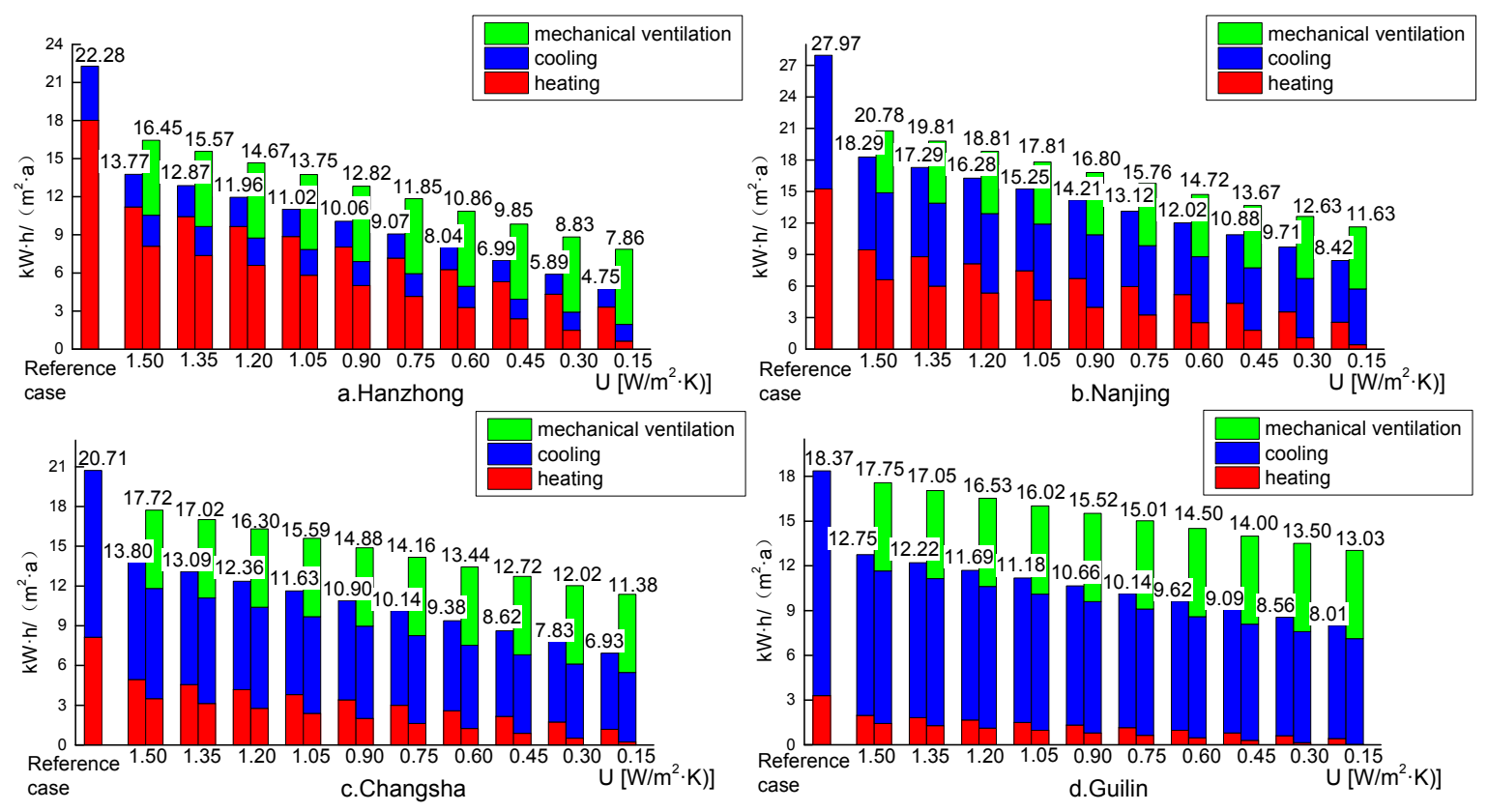

Figure 19. Annual electricity consumption in other cities (a) Hanzhong; (b) Nanjing; (c) Changsha; (d) Guilin. (At a certain U value, former column represents Mode 2, latter column represents Mode 3).

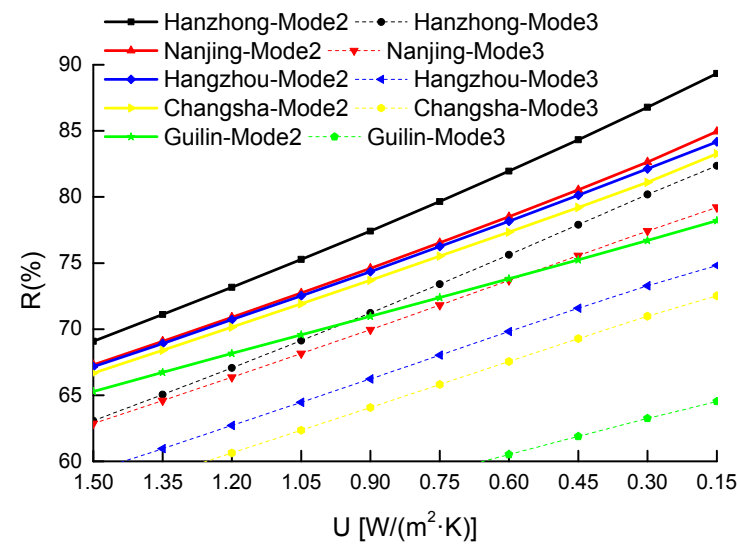

Figure 20. Energy saving rate variation with exterior wall heat transfer coefficient.

Recently passive houses have become one of the hotspot issues in building of energy-saving houses in China. This paper analyzed the effect airtightness and exterior wall insulation on energy consumption of passive houses in HSCW. Future research could focus on the economic efficiency and indoor environmental comfort, and from these two aspects, the adaptability of passive houses in this region can be evaluated more completely.

\section{Conclusions}

- Summer and winter are both cooler in Berlin, and that would be more significant in summer. It will generate a significant difference in actual occupant energy-consuming behaviors and building energy consumption composition. 
- Decrease of $\mathrm{ACH}$ can reduce annual heating and cooling load, and the effect on heating load is more remarkable. Well-organized natural ventilation is quite beneficial to cooling and energy-saving. Superb airtightness $\left(\mathrm{ACH}_{50}=0.6 \mathrm{ac} / \mathrm{h}\right)$ with mechanical ventilation may generate higher electricity consumption because the reduction of heating and cooling consumption is not enough to neutralize the accompanying mechanical ventilation consumption. The most energy-saving ventilation mode in $\mathrm{HSCW}$ is $0.5 \mathrm{ac} / \mathrm{h}$ for $\mathrm{ACH}$ with well-organized natural ventilation.

- Improvement of exterior wall insulation can reduce annual heating and cooling load, and the effect on heating load is more remarkable. In colder cities the energy-saving effect is heightened by decreasing the exterior wall heat transfer coefficient.

- This paper proposes that the ratio of heating and cooling electricity consumption $(r)$ should be an important index in passive house energy-saving effect evaluation, as it would contribute to reasonable selection of ventilation mode and exterior wall heat transfer coefficient, and benefit the healthy development of passive houses in HSCW.

Author Contributions: Xiaoqian Qian contributed to the conception of this study and the development of its methodology. Xin Fu and Lina Wang performed the experiments. Xin Fu performed the simulation calculation, analyzed the data and wrote the manuscript. All authors have read and approved the final manuscript.

Conflicts of Interest: The authors declare no conflict of interest.

\section{Abbreviations}

The following abbreviations are used in this manuscript:

$\begin{array}{ll}\text { HSCW } & \text { hot summer and cold winter zone in China } \\ r & \text { the ratio of heating and cooling electricity consumption } \\ \mathrm{PHI} & \text { Passive House Institute } \\ \mathrm{T}_{\mathrm{IS}} & \text { internal surface temperature of exterior wall }\left({ }^{\circ} \mathrm{C}\right) \\ \mathrm{T}_{\mathrm{ES}} & \text { external surface temperature of exterior wall }\left({ }^{\circ} \mathrm{C}\right) \\ \mathrm{AC} & \text { air conditioning } \\ \mathrm{SHGC} & \text { solar heat gain coefficient } \\ \mathrm{U} & \text { heat transfer coefficient }\left(\mathrm{W} / \mathrm{m}^{2} \cdot \mathrm{K}\right) \\ \mathrm{COP} & \text { the coefficient of performance } \\ \mathrm{T}_{\mathrm{C}} & \text { the average temperature in the coldest month } \\ \mathrm{T}_{\mathrm{H}} & \text { the average temperature in the hottest month } \\ \mathrm{X}_{\mathrm{C}} & \text { the numbers of days in which the daily average temperature is less than or equal to } 5{ }^{\circ} \mathrm{C} \\ \mathrm{X}_{\mathrm{H}} & \text { the numbers of days in which the daily average temperature is more than or equal to } 25^{\circ} \mathrm{C} \\ \mathrm{ACH} & \text { average natural infiltration rate }(\mathrm{ac} / \mathrm{h}) \\ \mathrm{ACH} & \text { average natural infiltration rate when the building envelope is subjected to a } 50 \text { Pa pressure }(\mathrm{ac} / \mathrm{h}) \\ \mathrm{Q}_{\mathrm{AC}} & \text { annual heating or cooling load }\left(\mathrm{kW} \cdot \mathrm{h} / \mathrm{m}^{2} \cdot \mathrm{a}\right) \\ \mathrm{Q}_{\mathrm{SO}} & \text { solar heat gain through exterior windows }\left(\mathrm{kW} \cdot \mathrm{h} / \mathrm{m}^{2} \cdot \mathrm{a}\right) \\ \mathrm{Q}_{\mathrm{I}} & \text { internal heat gain }\left(\mathrm{kW} \cdot \mathrm{h} / \mathrm{m}^{2} \cdot \mathrm{a}\right) \\ \mathrm{Q}_{\mathrm{MV}} & \text { heat gain or loss for mechanical ventilation }\left(\mathrm{kW} \cdot \mathrm{h} / \mathrm{m}^{2} \cdot \mathrm{a}\right) \\ \mathrm{Q}_{\mathrm{NV}} & \text { heat gain or loss for natural ventilation }\left(\mathrm{kW} \cdot \mathrm{h} / \mathrm{m}^{2} \cdot \mathrm{a}\right) \\ \mathrm{Q}_{\mathrm{INF}} & \text { heat gain or loss for natural infiltration }\left(\mathrm{kW} \cdot \mathrm{h} / \mathrm{m}^{2} \cdot \mathrm{a}\right) \\ \mathrm{Q}_{\mathrm{E}} & \text { heat gain or loss through envelope }\left(\mathrm{kW} \cdot \mathrm{h} / \mathrm{m} \mathrm{m}^{2} \cdot \mathrm{a}\right) \\ \mathrm{HE} & \text { annual heating electricity consumption }\left(\mathrm{kW} \cdot \mathrm{h} / \mathrm{m}^{2} \cdot \mathrm{a}\right) \\ \mathrm{CE} & \text { annual cooling electricity consumption }\left(\mathrm{kW} \cdot \mathrm{h} / \mathrm{m}^{2} \cdot \mathrm{a}\right) \\ \mathrm{AE} & \text { annual total electricity consumption }\left(\mathrm{kW} \cdot \mathrm{h} / \mathrm{m}^{2} \cdot \mathrm{a}\right) \\ \mathrm{T}_{\mathrm{NA}} & \text { natural indoor temperature }\left({ }^{\circ} \mathrm{C}\right) \\ \mathrm{R} & \text { energy saving rate }\end{array}$

\section{References}

1. Yu, J.; Yang, C.; Tian, L.; Liao, D. A study on optimum insulation thicknesses of external walls in hot summer and cold winter zone of China. Appl. Energy 2009, 86, 2520-2529. [CrossRef] 
2. Chow, D.H.C.; Li, Z.; Darkwa, J. The effectiveness of retrofitting existing public buildings in face of future climate change in the hot summer and cold winter region of China. Energy Build. 2013, 57, 176-186. [CrossRef]

3. Ichinose, T.; Lei, L.; Lin, Y. Impacts of shading effect from nearby buildings on heating and cooling energy consumption in hot summer and cold winter zone of China. Energy Build. 2017, 136, 199-210. [CrossRef]

4. Zhang, S.; Zhang, L.; Wei, H.; Jing, J.; Zhou, X.; Zhang, X. Field testing and performance analyses of ground source heat pump systems for residential applications in Hot Summer and Cold Winter area in China. Energy Build. 2016, 133, 615-627. [CrossRef]

5. Lu, S.; Tang, X.; Ji, L.; Tu, D. Research on energy-saving optimization for the performance parameters of rural-building shape and envelopee by TRNSYS-GenOpt in hot summer and cold winter zone of China. Sustainability 2017, 9, 294. [CrossRef]

6. Chen, X.; Wen, Y.; Li, N. Energy efficiency and sustainability evaluation of space and water heating in urban residential buildings of the hot summer and cold winter zone in China. Sustainability 2016, 8, 989. [CrossRef]

7. Passive House Institute. Certification Criteria for Residential Passive House Buildings. 2015. Available online: http:/ / passiv.de/downloads/03_certification_criteria_residential_en.pdf (accessed on 15 January 2015).

8. Younes, C.; Abi Shdid, C.; Bitsuamlak, G. Air infiltration through building envelopees: A review. J. Build. Phys. 2012, 35, 267-302. [CrossRef]

9. Schnieders, J.; Feist, W.; Rongen, L. Passive houses for different climate zones. Energy Build. 2015, 105, 71-87. [CrossRef]

10. Mihai, M.; Tanasiev, V.; Dinca, C.; Badea, A.; Vidu, R. Passive house analysis in terms of energy performance. Energy Build. 2017, 144, 74-86. [CrossRef]

11. Persson, M.-L.; Roos, A.; Wall, M. Influence of window size on the energy balance of low energy houses. Energy Build. 2006, 38, 181-188. [CrossRef]

12. Audenaert, A.; De Cleyn, S.H.; Vankerckhove, B. Economic analysis of passive houses and low-energy houses compared with standard houses. Energy Policy 2008, 36, 47-55. [CrossRef]

13. Dan, D.; Tanasa, C.; Stoian, V.; Brata, S.; Stoian, D.; Nagy Gyorgy, T.; Florut, S.C. Passive house design-An efficient solution for residential buildings in Romania. Energy Sustain. 2016, 32, 99-109. [CrossRef]

14. Georges, L.; Skreiberg, Ø.; Novakovic, V. On the proper integration of wood stoves in passive houses under cold climates. Energy Build. 2014, 72, 87-95. [CrossRef]

15. Zhang, X. Passive House Construction Situation in China. Available online: http://www.passivehouse.org. $\mathrm{cn} / \mathrm{al} /$ (accessed on 23 June 2017). (In Chinese)

16. Feist, W.; Schnieders, J.; Dorer, V.; Haas, A. Re-inventing air heating: Convenient and comfortable within the frame of the passive house concept. Energy Build. 2005, 37, 1186-1203. [CrossRef]

17. Crawley, D.B.; Lawrie, L.K.; Winkelmann, F.C.; Buhl, W.F.; Huang, Y.J.; Pedersen, C.O.; Strand, R.K.; Liesen, R.J.; Fisher, D.E.; White, M.J.; et al. EnergyPlus: Creating a new-generation building energy simulation program. Energy Build. 2001, 33, 319-331. [CrossRef]

18. Tindale, A. Designbuilder and energyplus. Build. Energy Simul. User News 2004, 25, 2-5.

19. Ministry of Housing and Urban-Rural development of China. Design Standard for Energy Efficiency of Residential Buildings in Hot Summer and Cold Winter Zone; JGJ 134-2010; China Architecture and Building Press: Beijing, China, 2010. (In Chinese)

20. Bureau of Quality and Technical Supervision of China; Ministry of Construction of China. Standard of Climatic Regionalization for Architecture; GB 50178-93; China Planning Press: Beijing, China, 2001. (In Chinese)

21. Oie, L.; Nafstad, P.; Botten, G.; Magnus, P.; Jaakkola, J.K. Ventilation in homes and bronchial obstruction in young children. Epidemiology 1999, 10, 294-299. [CrossRef] [PubMed]

22. Dimitroulopoulou, C. Ventilation in European dwellings: A review. Build. Environ. 2012, 47, 109-125. [CrossRef]

23. China Architecture Science Institute. Design Standard for Energy Efficiency of Residential Buildings in Cold and Severe Cold Zone; JGJ 26-2010; China Architecture and Building Press: Beijing, China, 2010. (In Chinese)

24. Chen, S.; Levine, M.D.; Li, H.; Yowargana, P.; Xie, L. Measured air tightness performance of residential buildings in North China and its influence on district space heating energy use. Energy Build. 2012, 51, 157-164. [CrossRef]

(C) 2017 by the authors. Licensee MDPI, Basel, Switzerland. This article is an open access article distributed under the terms and conditions of the Creative Commons Attribution (CC BY) license (http:/ / creativecommons.org/licenses/by/4.0/). 